\title{
EFFECT OF IRRIGATION IMPROVEMENT ON CROP PATTERN AND CROP WATER REQUIREMENTS USING REMOTE SENSING AND GIS TECHNIQUES \\ El-Hadidy, E.M. ${ }^{\star}$, A. A. Belal ${ }^{\star *}$; A. M. Mosa ${ }^{\star}$; A. A. Elnaggar ${ }^{\star}$ and H.M. Aboelsoud" \\ Soil Dept, Faculty of Agric. Mansura Univ. **National Authority for Remote Sensing and Space Sciences (NARSS) \\ ${ }^{* * *}$ Soil, Water and Environment Research Institute, ARC
}

\begin{abstract}
The cropping pattern and crop evapotranspiration (ETc) of a region are mainly affected by the efficiency of the irrigation system. The objectives of this study were to investigate the impact of irrigation projects in North Delta on crop pattern and water consumption. Remote sensing (RS) and GIS techniques were used to evaluate crop pattern and ETc on El Moheet Canal, North Delta. This canal was subject to irrigation improvement practices (Mesqas and Marwas). This study was carried out during two summer growing seasons (2011, before the improvement and 2013, after the improvement).

The obtained results showed that the pixels of the selected canal in both summer growing seasons were classified into 7 land uses (rice, cotton, seed melon, maize, open water, roads, and urban). Before the improvement, cotton was the dominant crop $(42.7 \%)$ followed by rice $(33.3 \%)$, seed melon $(14.5 \%)$, and maize $(9.5 \%)$. However, after the improvement, rice was the dominant crop $(74.1 \%)$, followed by seed melon (10.7\%), cotton (9.2\%), and maize $(6.0 \%)$. The percentage of rice was strongly increased by about $113 \%$ after the improvement. On the other hand, cotton, maize and seed melon were significantly decreased by about 79, 40 and $29 \%$, respectively, when compared with their areas before the improvement. It could be concluded from the Landsat data that the overall ETc was decreased after irrigation improvement in 2013 by about $4.3 \%$, whereas water requirement/ha was decreased by about $6.3 \%$.

The obtained images also showed that the cultivated area was decreased from 2011 to 2013 by about $4.3 \%$ due to urbanization. However, the non-cultivated area was increased by about $25 \%$. Crop distribution and the equity in water distribution along the branch canal were improved due to irrigation improvement.

In conclusion, the improvement of the irrigation system saved irrigation water and raised the distribution equity of water.

Keywords:Remote Sensing, GIS, ET, crop water requirement, El Moheet Canal, North Nile Delta
\end{abstract}

\section{INTRODUCTION}

Water management has become a crucial issue particularly in arid and semi arid zones, which are characterized by scarce or limited water resources. Conserving water resources is a priority for the Egyptian Government through improving the irrigation systems. The World Vision of Water for Food and Rural Development (Hofwegen and Svendsen, 2000) showed that by 2025 the world population would increase by 2 billion inhabitants to a total of approximately 8 billion people. Water requirement critical to livelihood including food production is $1700 \mathrm{~m}^{3} /$ capita. This water is 
not available for everybody; nearly one-third of the world's population will live in regions that will experience severe water scarcity. Major irrigation projects viz. Irrigation Improvement Projects (IIP) and Irrigation Improvement and Integration Management Project (IIIMP) in the Northern parts of Nile Delta serve as an advantage to the farming community for enhancing the agricultural production and water saving. Introduction of irrigation results in major changes in cropping systems and water consumption.

The cropping pattern and crop evapotranspiration $\left(\mathrm{ET}_{\mathrm{c}}\right)$ of a region are mainly affected by water availability and irrigation system efficiency. The cropping pattern of a region depends mainly upon the nature and quantum of irrigation water available. It is essential to study the local cropping patterns with respect to the soil suitability and water availability at micro scale. The estimation of crop pattern and $\mathrm{ET}_{\mathrm{c}}$ in a wide area through the earth observation needs huge efforts, costs and time. Therefore, remote sensing and GIS techniques have to be used. It is necessary to estimate the ET for the entire selected area. Although, remote sensing techniques are considered for the entire area estimation of ET, the use of satellite imagery is investigated to establish such relationships between ET and crop pattern and the vegetation production.

Crop acreage is primary information needed for water allocation and irrigation scheduling (Bastiaanssen, 1998). Remote sensing could be used for estimation of crop type, crop yield, and soil survey mapping for agricultural research (Kurucu et al., 2000). Bos et al. (2001) reported that remote sensing can be used in monitoring irrigation and drainage systems across larger areas and identification of local crop classes. Öztekin (2012) monitored and determined the land use types using the low cost satellite images and GIS technique, where crop types and their coordinates were also determined and recorded during the field work. WaterWatch (2003) used remote sensing to study the distribution and $\mathrm{ET}_{\mathrm{C}}$ of rice and cotton as affected by irrigation improvement in North Western Nile Delta. They observed an increase in rice at the expense of cotton as a result of irrigation improvement and the percentage of rice was slightly decreased from the head to the tail of canal, whereas cotton remained quite homogeneous over the entire area. Also, they observed a slight decrease in $\mathrm{ET}_{\mathrm{c}}$ from head to tail of canals for rice and $E T_{c}$, although it was slightly increased for cotton and the head-tail differences in water availability were not showed up in the $\mathrm{ET}_{\mathrm{c}}$ levels.

Denis (2013) reported that about ninety percent of annual precipitation is consumed in ET in semi-arid regions. Consequently, accurate estimates of ET are required for irrigation water management. Accurate estimation of ET is essential for hydrologic water balance, irrigation scheduling, and water resources planning and management. Therefore, Remote Sensing and GIS techniques with Hydrological Models are used to develop a friendly decision support system for estimating actual crop ETc. The indirect ET estimation methods are based on climatic data which vary from empirical relationships to complex methods. These different methods of ET estimation can be grouped into two types based on the techniques used. The first traditional methods based on GIS and the second is the remote sensing methods (Almhab and Busu, 2008). Ahmad et al. (2004) and Raju et al. 
(2008) reported that remotely sensed estimates of $\mathrm{ET}_{\mathrm{C}}$ can directly represent the crop growth conditions and is better than field measurements. Furthermore the integration of various space borne platforms for more precise information on estimation of $E T_{c}$ is encouraged and is necessary in view of the actual image limitations (Anderson et al., 2012). Elhaddad et al. (2007) reported that the conventional methods estimate $\mathrm{ET}_{0}$ from meteorological data and apply crop coefficients to estimate $E T_{c}$, whereas the remote sensing models are able to directly estimate $E T_{c}$ in a specific field due to factors such as water shortages or salinity impacts. Bleiweiss et al. (2010) used the spatial satellite remote sensing to estimate ET and then, biomass can be calculated to be linked with crop yield. This could provide an excellent opportunity to evaluate the impact of various parameters such as crop type, field size, soil, etc on the economic return from irrigated agriculture.

The objectives of this study were to investigate the impact of irrigation projects in Nile Delta on the crop pattern and water consumptive. I was also to monitor and determine the land use classification and crop water consumption based on satellite images.

\section{MATERIALS AND METHODS:}

\section{Descriptions of the study area:}

The study area of El-Moheet canal (640 ha) is located in North Nile Delta and was completely under improved surface irrigation. El-Moheet canal (3.500 Km length) lies between $31^{\circ} 11^{\prime} 14^{\prime \prime}$ and $31^{\circ} 13^{\prime} 06^{\prime \prime} \mathrm{N}$ and $31^{\circ} 00^{\prime} 48^{\prime \prime}$ and $31^{\circ} 02^{\prime} 20^{\prime \prime} \mathrm{E}$ as illustrated in Figure (1). Surface elevation is about 6 meters above the sea level. This area has a Mediterranean-type climate, typically hot-dry summer and mild-rainy winter. The mean annual temperature ranges between 5.7 and $34.2{ }^{\circ} \mathrm{C}$. The average rainfall is about $150 \mathrm{~mm} / \mathrm{yr}$. Relative humidity ranges from $59.3 \%$ in May to $72.7 \%$ in January. The average daily sunshine hours ranges between 6.2 hours in January and 11.7 hours in June. Daily meteorological data were obtained from the meteorological station of the Rice Centre at Kafr El-Sheikh Research Station. These data include the minimum and maximum air temperature, minimum and maximum relative humidity, wind speed, sunshine hours, Pan Evaporation and rainfall.

Soils in the selected area are alluvial clayey and in general nonsaline soils (EC values vary from 2 to $3 \mathrm{dSm}^{-1}$ ). Large part of the area is under subsurface drainage and water table is deeper than one meter below the ground surface. 
El-Hadidy, E. M. et al.

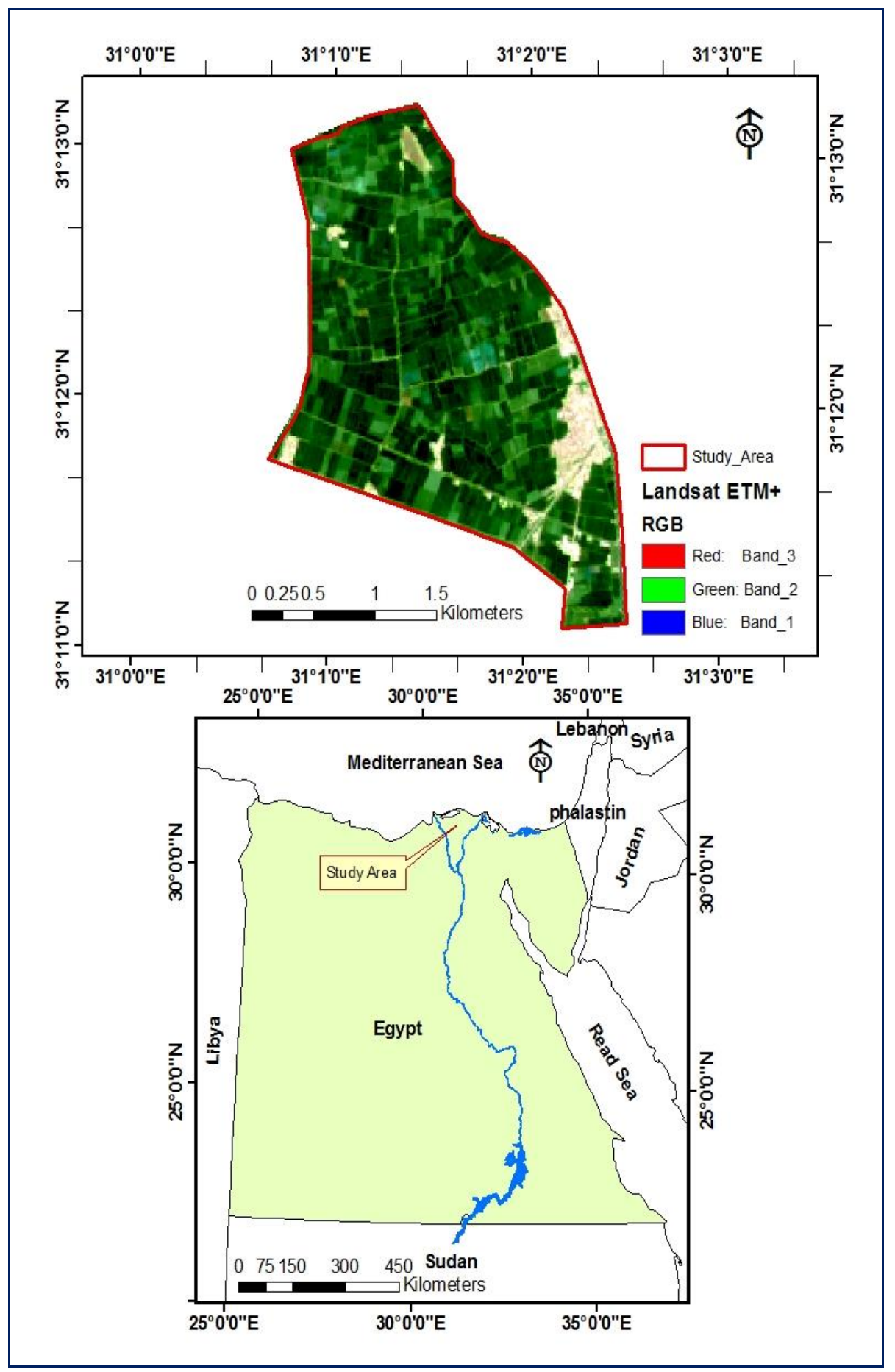

Fig (1): Location of the studied area (El-Moheet Branch Canal). 


\section{Remote Sensing Data Availability:}

Remote sensing provides spatial coverage through the measurement of reflected and emitted electromagnetic radiations, across a wide range of wavelength from the earth's surface and the surrounding atmosphere. Remote sensing is the act of collecting data without physical contact with the studied object. Landsat imagery was used to calculate Land Surface Temperature (LST), Normalized Difference Vegetation Index (NDVI) and $\mathrm{ET}_{0}$. Gap-Filling of Landsat 7 SLC-off Images:

Single scenes of Landsat 7 SLC-off images were filled using the Focal Analysis Screenshot module under ERDAS Imagine. This method was designed to modify neighboring pixels in a single Landsat 7 SLC-off scene, creating a final aesthetic image. No scientific analysis of accuracy is guaranteed using this method. This method was designed using ERDAS Imagine $^{\mathrm{Tm*}}$, along with ENVI ${ }^{\mathrm{TM} *}$ or Adobe Photoshop ${ }^{\mathrm{TM}}{ }^{*}$ for final filled-image verification.

\section{Remote Sensing Data:}

Two Landsat 7 images (path 177, row 38) were used in this study. These images were acquired during the two summer seasons (2011 and 2013) before and after irrigation improvement.

\section{Image Preprocessing:}

Pre-processing of satellite data is necessary not only to remove the sensor errors during data acquisition but also display correction, band selection, reducing data dimensionality and to reduce the computational complexity. Radiometric, geometric, and atmospheric correction were carried out on the studied Landsat ETM+ image for better visualization enhancement.

\section{Geometric Correction:}

The studied images were geometrically corrected using image to image correction method. Images were projected using the UTM projection (WGS-1984 datum, zone $36 \mathrm{~N}$ ). A subset of each image was used for spectral classification.

\section{Atmospheric Correction using FLAASH Tool:}

Atmospheric correction refers to the removal of atmospheric components from the image. This step is necessary for better reflectance. Atmospheric correction was done using FLAASH (Fast Line-of-sight Atmospheric Analysis of Spectral Hypecubes) tool based on MODTRAN algorithm in ENVI 5.1. From ENVI, the Landsat image could be read directly but for the atmospheric correction, the native file in BSQ format was used. This also has to be converted to either BIL or BIP format for the FLAASH tool.

\section{Crop classification:}

Initial unsupervised classification was applied, which is an automated cluster analysis technique that uses a minimum spectral distance cluster algorithm to assign a pixel to a cluster of pixels with similar attribute. Supervised classification was used for accurate and precise clustering of pixels into land use/land cover classes (Campbell, 1996).

In this study, Sub-pixel supervised image classification was used. Landsat ETM+ imagery, acquired in July $17^{\text {th }}, 2011$, and July $15^{\text {th }} 2013$ with 
$30 \mathrm{~m}$ ground resolution were used to record crop classification. Cropclassification of the two seasons was used to reflect crop situation before and after irrigation improvement. Head-tail analysis for the selected canal was performed. Field survey was carried out during July 2011 and 2013 to identify the locations of the grown summer crops. This selected period was suitable for spotting rice, cotton, maize and seed melon. About 80 fields for both summer seasons were visited and inspected. The coordinates of the four corners for each selected field were recorded using the GPS (Modil Gramin). Land use and crop classification were extracted and identified from the satellite images during one particular day (image acquisition date). Errors in land cover classification using remote sensing were resulted from differences in soil background, positional errors, land cover mixtures, or human errors. Therefore, accuracy assessment was done using 20 random points for each of the studied areas.

\section{Calculation of $\mathrm{ET}_{\mathrm{o}}$ :}

FAO-Penman-Montieth Method:

$\mathrm{ET}_{0}$ was calculated from the meteorological data using the FAOPenman-Montieth formula. This formula developed based on an empirical method to calculate the $E T_{0}$, which was adjusted by crop coefficient $\left(k_{c}\right)$ to calculate $\mathrm{ET}_{\mathrm{c}}$ (Hargreaves et al., 1985 and Popova et al., 2005). Meteorological parameters used in this equation were obtained from Sakha meteorological station. The following equation was used:

$$
\begin{aligned}
& \text { ET0 }=\frac{0.408 \Delta\left(R_{n}-G\right)+y\left[\frac{900}{T+273}\right] U_{2}\left(e_{s}-e_{a}\right)}{\Delta+y\left(1+0.34 u_{2}\right)} \\
& \text { Where: } \\
& \mathrm{ET}_{0} \text {, reference evapotranspiration [mm day }{ }^{-1} \text {, } \\
& \mathrm{R}_{\mathrm{rb}} \text {, net radiation at the crop surface }\left[\mathrm{MJ} \mathrm{m}^{2} \mathrm{day}^{-1}\right]^{-1} \\
& \mathrm{G} \text {, soil heat flux density [MJ } \mathrm{M}^{2} \text { day'], } \\
& \mathrm{T} \text {, mean daily air temperature at } 2 \mathrm{~m} \text { height }\left[{ }^{\mathrm{C}} \mathrm{C}\right] \text {, } \\
& \mathrm{u}_{2} \text {, wind speed at } 2 \mathrm{~m} \text { height }\left[\mathrm{ms}^{-1}\right] \text {, } \\
& \mathrm{e}_{\mathrm{s}} \text {, saturation vapour pressure [kPa], } \\
& \mathrm{e}_{\mathrm{a}} \text {, actual vapour pressure }[\mathrm{kPa}] \text {, } \\
& \mathrm{e}_{\mathrm{s}}-\mathrm{e}_{a} \text {, saturation vapour pressure deficit }[\mathrm{kPa}] \text {, }
\end{aligned}
$$

\section{Hargreaves Method:}

This method uses minimum amount of data (i.e., maximum, minimum and average temperature, number of the day, and latitude). $\mathrm{ET}_{0}$ was calculated from the meteorological data using Hargreaves formula.

This formula was also developed based on an empirical method to calculate $\mathrm{ET}_{0}$, after that it was calibrated with FAO-Penman-Montieth under the same area with the same data. Calibrated Hargreaves was used also to calculate $E T_{0}$ from predicted air temperature $\left(T_{\text {air }}\right)$ derived from land surface temperature (LST). $\mathrm{ET}_{\mathrm{o}}$ adjusted by crop coefficient to calculate $\mathrm{ET}_{\mathrm{C}}$.

\section{The following equations were used:}

$E T_{0}=0.0135(K T) R_{a}(T D) 0.5(T+17.8)$

$\mathrm{KT}=0.00185(\mathrm{TD}) 2-0.0433(\mathrm{TD})+0.4023$ 
$\mathrm{TD}=\mathrm{T}_{\max }-\mathrm{T}_{\min }$

Where,

$E T_{0}$ is the reference evapotranspiration $(\mathrm{mm} /$ day);

$\mathrm{T}$ is the monthly average temperature $\left({ }^{\circ} \mathrm{C}\right)$;

$\mathrm{T}_{\max }$ and $\mathrm{T}_{\min }$ are monthly maximum and minimum temperature $\left({ }^{\circ} \mathrm{C}\right)$, respectively.

$R_{a}$ is the water equivalent of the extraterrestrial radiation (MJ/day), which was calculated based on the latitude and also the specific month in study area.

$\mathrm{KT}$ is an empirical constant that was calculated from the equation (2).

Relation between $\mathrm{ET}_{0}$ obtained from Hargreaves and FAO-PenmanMonteith methods was produced by El-Shirbeny (2012) as follow:

$$
y=0.5826 x-0.1066 \quad(R 2=0.7829)
$$

A logarithmic relation between LST and $T_{\text {air }}$ was established and $R^{2}$ was 0.74 according to El-Shirbeny (2012) as follow:

$$
y=10.568 \operatorname{Ln}(x)-8.5825 \quad(R 2=0.7423)
$$

The land surface temperature is calculated using equations (1-3)

$\mathrm{T}=\mathrm{T}_{61}+\left[1.29+0.28\left(\mathrm{~T}_{61}-\mathrm{T}_{62}\right)\right]\left(\mathrm{T}_{61}-\mathrm{T}_{\square 2}\right)+45\left(1-\varepsilon_{4}\right)-40 \Delta \varepsilon$

(1)

$\varepsilon_{4}=0.9897+0.029 \ln (\mathbf{N D} \square \mathbf{I})$

(2)

$$
\Delta \varepsilon=0.01019+0.01344 \ln (\mathbf{N D} \square \mathbf{I})
$$

(3)

Where: $T_{61}, T_{62}$ are the brightness temperature of the thermal bands $\left(T_{61}\right.$ and $\mathrm{T}_{62}$ ) of remote sensing data, $\varepsilon_{4}$ the surface emissivity of $\mathrm{T}_{61}$ channel, and $\Delta \varepsilon$ is the differences in surface emissivity between the $T_{61}, T_{62}$ channels.

2.4. Conveyance efficiency $\left(E_{\text {conv }}\right)$ :

$E_{\text {conv }}$ was calculated using the following equation:

Econv $(\%)=\frac{\text { Water discharge at tail of the watercourse }\left(\frac{L}{S}\right) * 100}{\text { Tater discharge at head of the watercourse }\left(\frac{L}{S}\right)}$

Water discharge was measured by electromagnetic current meter (KENEK Corporation LP 30) in three unimproved field waterways. The $E_{\text {conv }}$ values were found to be 81,85 and $88 \%$ for the three waterways. This means that the The $E_{\text {conv }}$ values ranged between $80-90 \%$.

Water requirements:

Water requirements $\left(\mathrm{m}^{3} / \mathrm{ha}\right)$ were calculated using the following equation:

Crop water requirements $=E T c\left(m^{3}\right) /$ irrigation efficiency

Soil salinity:

Soil salinity $\left(\mathrm{dSm}^{-1}\right)$ was measured in the field using the TDR and by measuring the electrical conductivity (EC) in the soil paste extract at theses depths 0-30, 30-60 and 60-90 cm (Jackson, 1967). 


\section{RESULTS AND DISCUSSION}

\section{Land use classification:}

Most of the Egyptian cropping systems produce two crops per year, one in the winter season and another in the summer. Few crops were adapted to the temperature regimes of both seasons and the irrigation system was designed to provide water to meet the needs of the cropping system.

Differences in irrigation facilities and economic situation contribute in changing the cropping pattern. Part of the farmers have the intention of developing a stable cropping pattern under a given agro-climatic setup and they do not shift much from this position except to the extent dictated by price factors in adjusting acreage allocations.

Data in Table (1) and Figures (2) show that pixels of the selected canal (El-Moheet) could be classified into seven land uses. The obtained acreage of each crop and land use during data acquisition date in both summer seasons (2011 and 2013) revealed that cotton was the dominant crop before the improvement (42.7\%) followed by rice (33.3\%), seed melon $(14.5 \%)$ and maize $(9.5 \%)$. However, an opposite trend was recorded after the improvement, where rice was the dominant summer crop $(74.1 \%)$ followed by seed melon (10.7\%), cotton $(9.2 \%)$, and maize $(6.0 \%)$. The overall accuracy for land use classification in summer 2011 and 2103 were 92 and $82 \%$, respectively.

The percentage of rice was increased by about $113 \%$ after irrigation improvement. In the contrary of rice, cotton, maize and seed melon were clearly decreased after improvement (-79.3, -40.2 and $-29.3 \%$, respectively), when compared with their areas before the improvement .The most obvious difference in cropping patterns in El-Moheet canal was the replacement of cotton, seed melon and maize by rice after the improvement. The significant increase in rice area after the improvement could be attributed to the improvement in the availability of irrigation water as a result of irrigation improvement processes .Consequently, the equity of the irrigation water along the improved branch canal was also improved, especially at the tail end area. The obtained images also show that the planted area was decreased from 2011 to 2013 by about $4.3 \%$ due to urbanization.

Table(1):Summer crop classification extracted from Landsat Images before and after irrigation improvement.

\begin{tabular}{|l|c|c|c|c|c|c|c|c|c|c|c|}
\hline \multirow{2}{*}{ Crop } & \multicolumn{4}{|c|}{ Crop area (2011) } & \multicolumn{5}{c|}{ Crop area (2013) } & 13/11 \\
\cline { 2 - 14 } & Total & \% & Head & Middle & Tail & Total & $\%$ & Head & Middle & Tail & $\begin{array}{c}\mathbf{1} \\
\text { ratio } \\
+/-\end{array}$ \\
\hline Rice & 182 & 33.3 & 76.6 & 55.2 & 49.7 & 387 & 74.1 & 132.5 & 131.7 & 122.4 & 113.0 \\
\hline Cotton & 233 & 42.7 & 63.6 & 89.6 & 79.6 & 48 & 9.2 & 16.3 & 18.6 & 13.3 & -79.3 \\
\hline Maize & 52 & 9.5 & 18.4 & 17 & 16.6 & 31 & 6.0 & 8.6 & 12.6 & 9.8 & -40.2 \\
\hline S.melon & 79 & 14.5 & 30 & 29.8 & 19.3 & 56 & 10.7 & 23.2 & 17.7 & 15 & -29.3 \\
\hline Planted Area & 545 & 85.2 & 188.6 & 191.6 & 165.2 & 522 & 81.5 & 180.6 & 180.6 & 160.5 & -4.3 \\
\hline Water & 22 & 3.4 & 9.2 & 5.3 & 7.3 & 23 & 3.5 & 13.9 & 4.7 & 4.0 & 3.7 \\
\hline Rood & 47 & 7.3 & 20.6 & 13.3 & 12.6 & 65 & 10.2 & 26.4 & 19.7 & 18.9 & 39.8 \\
\hline Urban & 26 & 4.1 & 24 & 1.8 & 0.5 & 31 & 4.8 & 28.1 & 1.9 & 0.7 & 16.7 \\
\hline Unplanted Area & 95 & 14.8 & 53.8 & 20.4 & 20.4 & 118 & 18.5 & 68.4 & 26.3 & 23.6 & 25.1 \\
\hline Total & 640 & 100 & 242.4 & 212 & 185.6 & 640 & 100.0 & 249 & 206.9 & 184.1 & 0.0 \\
\hline
\end{tabular}



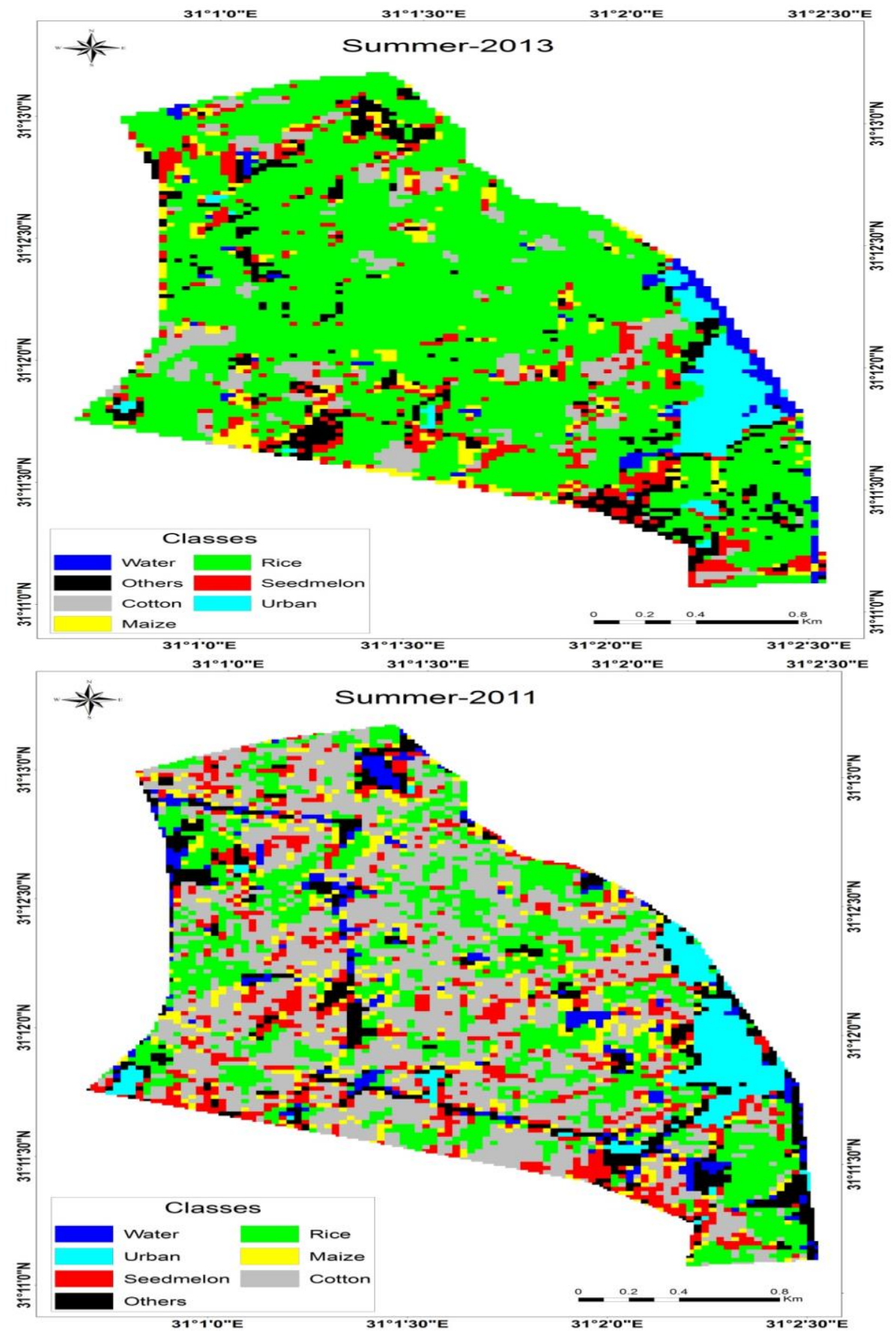

Fig. (2): Summer crop classification before the improvement (2011) and after the improvement (2013) extracted from Landsat Images. 
It was observed that the non-cultivated areas (i.e., roads, open water and urban) along the investigated canal were increased from 2011 to 2013 by about $25 \%$. This could be attributed to the significant increase in roads (39.8 $\%)$ due to the conversion of the earthen courses into buried pipe lines. On the other hand, the urban area was also increased from 26 ha in 2011 to 31 ha in 2013(about $25 \%$ ).

To provide a more generic overview of the head-tail situations for the investigated canal, the difference in crop presence between the head and tailend (divided into three equal area intervals from the inlet) was calculated and represented in Table (2). The most prominent head-tail pattern can be found with the main crops before and after irrigation improvement. In 2011 (before irrigation improvement) and 2013 (after irrigation improvement) the head-tail patterns for rice showed different patterns. The head/tail ratio for rice was decreased from 1.35 to 0.96 in 2011 and 2013, respectively. It means that rice was concentrated on the head reach before irrigation improvement, whereas after the improvement the rice area on the head third was approximately equal to that on the tail one (0.96). This trend could be attributed to the improvement the availability of irrigation water for the tail end as a result of irrigation improvement. On the contrary of rice, the head/tail ratio for cotton was increased from 0.7 to 1.08 in 2011 and 2013, respectively. Accordingly, within unimproved area, most of the rice area occupied the head reach, but most of the cotton area occupied the last reach. However, after the improvement of irrigation system, a reverse pattern was observed. The distribution of seed melon area along the investigated canal takes the same distribution tends before and after irrigation improvement (1.36 to 1.38). These results are in agreement with those obtained by WaterWatch (2003).

Consequently, with the completion of irrigation improvement in the selected canal, considerable changes are expected regarding to crop area and cropping system. Data collected during 2013 (Table 1) revealed an increase in area under production of rice by about $113 \%$. Cotton, which is another commercial crop, was decreased by about $79.3 \%$ in 2013. Simultaneous decrease was observed in the area of maize (about $40 \%$ ). The area under seed melon was slightly decreased after the improvement (about $29 \%$ ). The increase in rice area was observed after irrigation improvement (Table, 2), even though it needs relatively high water requirements. This change indicates that the irrigation improvement improves water equity along the branch canal especially in summer season. These results are in harmony with those obtained by WaterWatch (2003). 
Table (2): Head-tail analysis for crops along the branch canal before and after improvement.

\begin{tabular}{|l|c|c|c|c|c|c|c|c|}
\hline \multirow{2}{*}{ Crop } & \multicolumn{3}{c|}{ Crop \% (2011) } & \multicolumn{3}{c|}{ Crop \% (2013) } & \multicolumn{3}{c|}{ Head /Tail ratio } \\
\cline { 2 - 9 } & Head & Middle & Tail & Head & Middle & Tail & $\mathbf{2 0 1 1}$ & $\mathbf{2 0 1 3}$ \\
\hline Rice & 40.6 & 28.8 & 30.1 & 73.4 & 72.9 & 76.3 & 1.35 & 0.96 \\
\hline Cotton & 33.7 & 46.8 & 48.2 & 9 & 10.3 & 8.3 & 0.7 & 1.08 \\
\hline Maize & 9.8 & 8.9 & 10.1 & 4.8 & 7 & 6.1 & 0.97 & 0.79 \\
\hline S.melon & 15.9 & 15.5 & 11.7 & 12.8 & 9.8 & 9.3 & 1.36 & 1.38 \\
\hline Planted area & 77.8 & 90.4 & 89 & 69.4 & 87.2 & 87.6 & 0.87 & 0.79 \\
\hline Water & 3.8 & 2.5 & 3.9 & 5.3 & 2.3 & 2.2 & 0.97 & 2.41 \\
\hline Rood & 8.5 & 6.3 & 6.8 & 10.1 & 9.5 & 10.3 & 1.25 & 0.98 \\
\hline Urban & 9.9 & 0.8 & 0.3 & 10.8 & 0.9 & 0.4 & 33.0 & 27.0 \\
\hline Unplanted area & 22.2 & 9.6 & 11 & 30.6 & 12.8 & 12.4 & 2.02 & 2.47 \\
\hline
\end{tabular}

\section{Crop Evapotranspiration $\left(\mathrm{ET}_{\mathrm{c}}\right)$ :}

Differences in weather conditions have to be known prior to comparing crop evapotranspiration and crop yield between the two summer seasons in both 2011 and 2013. The accumulated daily air temperature and the accumulated sunshine duration were calculated and represented in Table (3). Estimation of the ETc values for both the investigated summer seasons was done for only three cloudless months (July, August and September). Good quality and cloud free satellite images are also expected in these months. The total degree days in summer season (2011) before irrigation improvement are 2433 vs. 2470 for summer season (2013) after irrigation improvement (based on the Sakha Stations). The summer season year (2011) had 1014 hours of bright sunshine, whereas summer season (2013) had 1019 hours of sun shine. Therefore, summer of 2013 had about $0.5 \%$ higher in sunshine hours and about $1.5 \%$ higher temperature. Consequently, the ET values between the two investigated seasons were not significantly affected by these differences in meteorological conditions. The total actual evapotranspiration $(E T C)$ and water requirements were calculated for rice, cotton, seed melon and maize in their respective growing calendar.

Table (3): The total degree days in summer seasons (2011 and 2013).

\begin{tabular}{|l|c|c|c|c|c|}
\hline \multirow{2}{*}{ Climate information } & \multirow{2}{*}{ Season } & \multicolumn{3}{|c|}{ Summer months } & \multirow{2}{*}{ Total } \\
\cline { 3 - 5 } & & July & August & Sept & \\
\hline \multirow{2}{*}{ Degree days } & 2011 & 842 & 827.7 & 763.5 & 2433 \\
\cline { 2 - 5 } & 2013 & 832 & 832.4 & 805.5 & 2470 \\
\hline \multirow{2}{*}{ Total sunshine } & 2011 & 357 & 352.6 & 304.9 & 1014 \\
\cline { 2 - 6 } & 2013 & 358 & 351.9 & 308.6 & 1019 \\
\hline
\end{tabular}

Data in Table (4) and Figures (3 - 5) represent the values of the actual evapotranspiration (ETc in $\mathrm{mm} /$ day) derived from Landsat images for the different crops along El-Moheet canal, their conversions into the seasonal values of ETc (m3/ha), and water requirements ( $\mathrm{m} 3 / \mathrm{ha}$ or $\mathrm{m} 3 / \mathrm{area})$. The obtained data showed that the average daily ETc in summer 2011 for rice, cotton, seed melon and maize were $6.1,5.17,4.77$ and $4.43 \mathrm{~mm} /$ day, respectively during the period from August first to the end of September. The total ETc for rice, cotton, seed melon and maize in the three months were 
$549,465,429$ and $399 \mathrm{~mm}$, respectively. The ETc in $\mathrm{m} 3 / \mathrm{ha}$ for this period were 5490, 4653, 4293 and $3987 \mathrm{m3} / \mathrm{ha}$, for the previous crops, respectively. Irrigation requirements were calculated by dividing ETc values by the irrigation efficiency at mesqa level. Irrigation efficiency at mesqa level before improvement was supposed to be $60 \%$ with rice and about $70 \%$ with the other crops. However, after the improvement the efficiency was raised to about $70 \%$ with rice and about $80 \%$ with the other crops due to raise in water efficiency by about $15 \%$. Therefore, water requirement (or water to be applied for irrigation) was $9150,6647,6133$ and $5696 \mathrm{~m} 3 / \mathrm{ha}$ with rice, cotton, seed melon and maize, respectively. The overall water requirements were calculated for the three months. This value was about $3989459 \mathrm{~m} 3$ /area. This means that each hectare needs about $81.3 \mathrm{~m} 3 /$ day during that period.

Table (4): Water consumption and water requirements for summer crops (2011)

\begin{tabular}{|l|c|c|c|c|c|c|c|c|}
\hline \multirow{2}{*}{ Crop } & Area & \multicolumn{2}{|c|}{ ETac( mm/day) } & Mean & ETc & \multicolumn{2}{c|}{ W.requirement } \\
\cline { 3 - 9 } & (ha) & July & Augst & Sept & $\mathbf{m m}$ & $\mathbf{~ m}^{\mathbf{3}} / \mathbf{h a}$ & $\mathbf{~ m}^{\mathbf{3}} / \mathbf{h a}$ & $\mathbf{m}^{\mathbf{3}} / \mathbf{a r e a}$ \\
\hline Rice & 181.5 & 7.0 & 5.7 & 5.6 & 6.10 & 5490 & 9150 & 1660725 \\
\hline Cotton & 232.8 & 5.9 & 5.1 & 4.5 & 5.17 & 4653 & 6647 & 1547422 \\
\hline S.Melon & 79.1 & 5.7 & 4.5 & 4.1 & 4.77 & 4293 & 6133 & 485120 \\
\hline Maize & 52 & 5.3 & 4.3 & 3.7 & 4.43 & 3987 & 5696 & 296192 \\
\hline Total & 545.4 & 23.9 & 19.6 & 17.9 & 20.5 & - & - & 3989459 \\
\hline Mean & - & - & - & - & 5.13 & 4606 & 7315 & - \\
\hline
\end{tabular}

In case of summer season 2013 (after the improvement), data in Table (5) and Figs (6-8) show that the average daily ETc for rice, cotton, seed melon and maize were $6.13,5.07,4.37$ and $4.03 \mathrm{~mm} /$ day, respectively from August first to the end of September. The actual water consumption was higher with rice when compared with the other crops during the considered months. The total ETc for rice, cotton, seed melon and maize in that period, were 552, 456, 393 and $363 \mathrm{~mm}$, respectively. The ETc in $\mathrm{m} 3 / \mathrm{ha}$ for this period was $5517,4563,3933$ and $3627 \mathrm{m3} / \mathrm{ha}$, for these crops, respectively. Therefore, water requirement for different crops (according to ETc and the irrigation efficiency) were 7881, 5704, 4916 and $4534 \mathrm{~m} 3 / \mathrm{ha}$ with rice, cotton, seed melon and maize, respectively. This means that each hectare needs about $79.6 \mathrm{~m} 3 /$ day during that period.

Table (5): Water consumption and water requirements for summer crops (2013)

\begin{tabular}{|c|c|c|c|c|c|c|c|c|}
\hline \multirow{2}{*}{ Crop } & \multirow{2}{*}{$\begin{array}{c}\text { Area } \\
\text { (ha) }\end{array}$} & \multicolumn{4}{|c|}{ ETc ( mm/day) } & \multirow{2}{*}{$\begin{array}{c}\text { ETc } \\
\mathrm{m} 3 / \mathrm{ha}\end{array}$} & \multicolumn{2}{|c|}{ W.requirement } \\
\hline & & July & August & Sept & mean & & m3/ha & m3/area \\
\hline Rice & 386.6 & 6.7 & 6.1 & 5.6 & 6.13 & 5517 & 7881 & 3046795 \\
\hline Cotton & 48.2 & 5.7 & 5.4 & 4.1 & 5.07 & 4563 & 5704 & 274932.8 \\
\hline S.Melon & 55.9 & 5.2 & 4.7 & 3.2 & 4.37 & 3933 & 4916 & 274804.4 \\
\hline Maize & 31.1 & 5.3 & 4.1 & 2.7 & 4.03 & 3627 & 4534 & 141007.4 \\
\hline Total & 521.8 & 22.9 & 20.3 & 15.6 & 19.6 & - & - & 3737539 \\
\hline Mean & - & - & - & - & 4.9 & 4410 & 7163 & - \\
\hline
\end{tabular}


J. Soil Sci. and Agric. Eng., Mansoura Univ., Vol. 5 (4), April, 2014

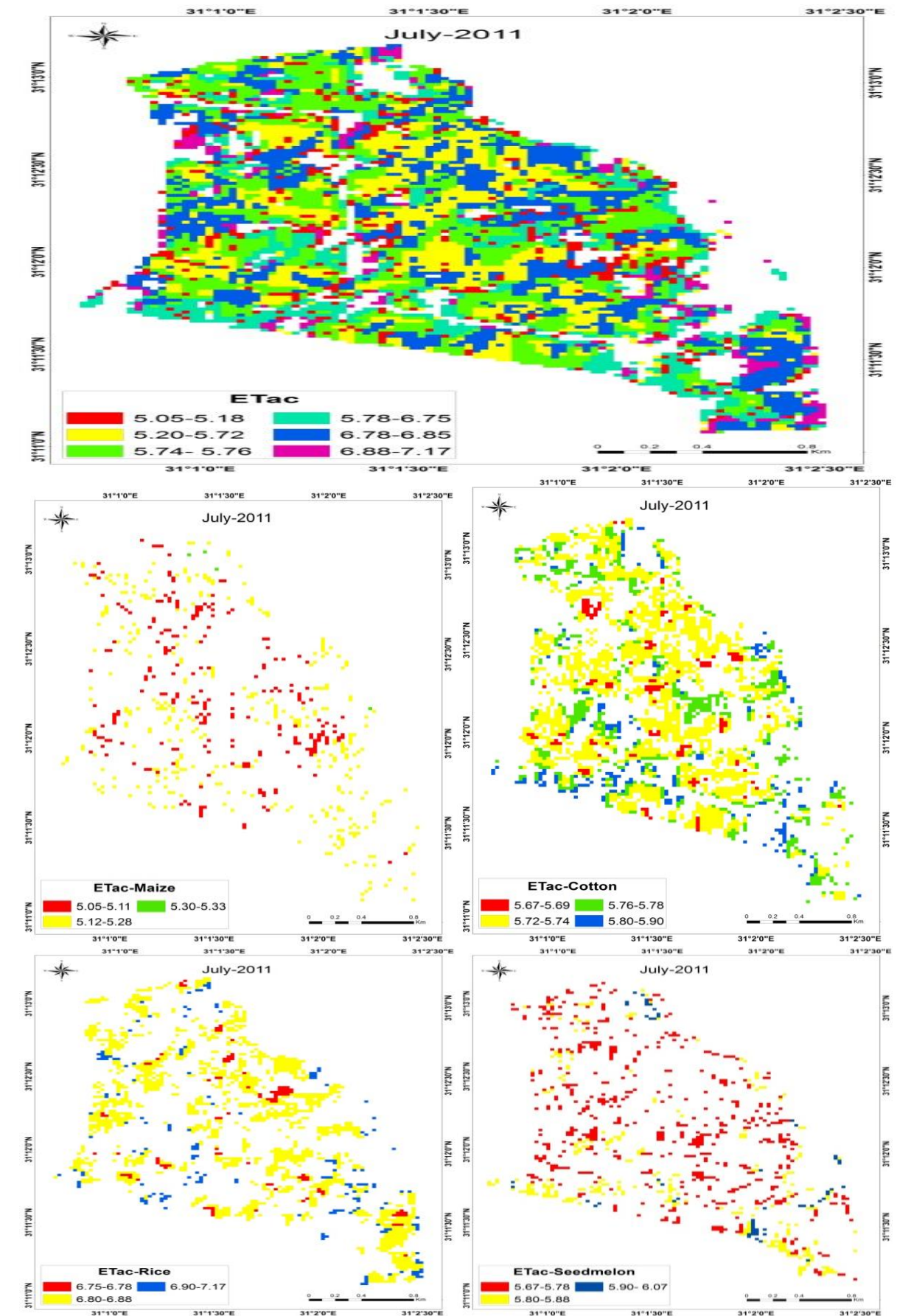

Fig (3): Estimated $\mathrm{ET}_{\mathrm{c}}(\mathrm{mm})$ for summer crops in July (2011) extracted from Landsat data. 


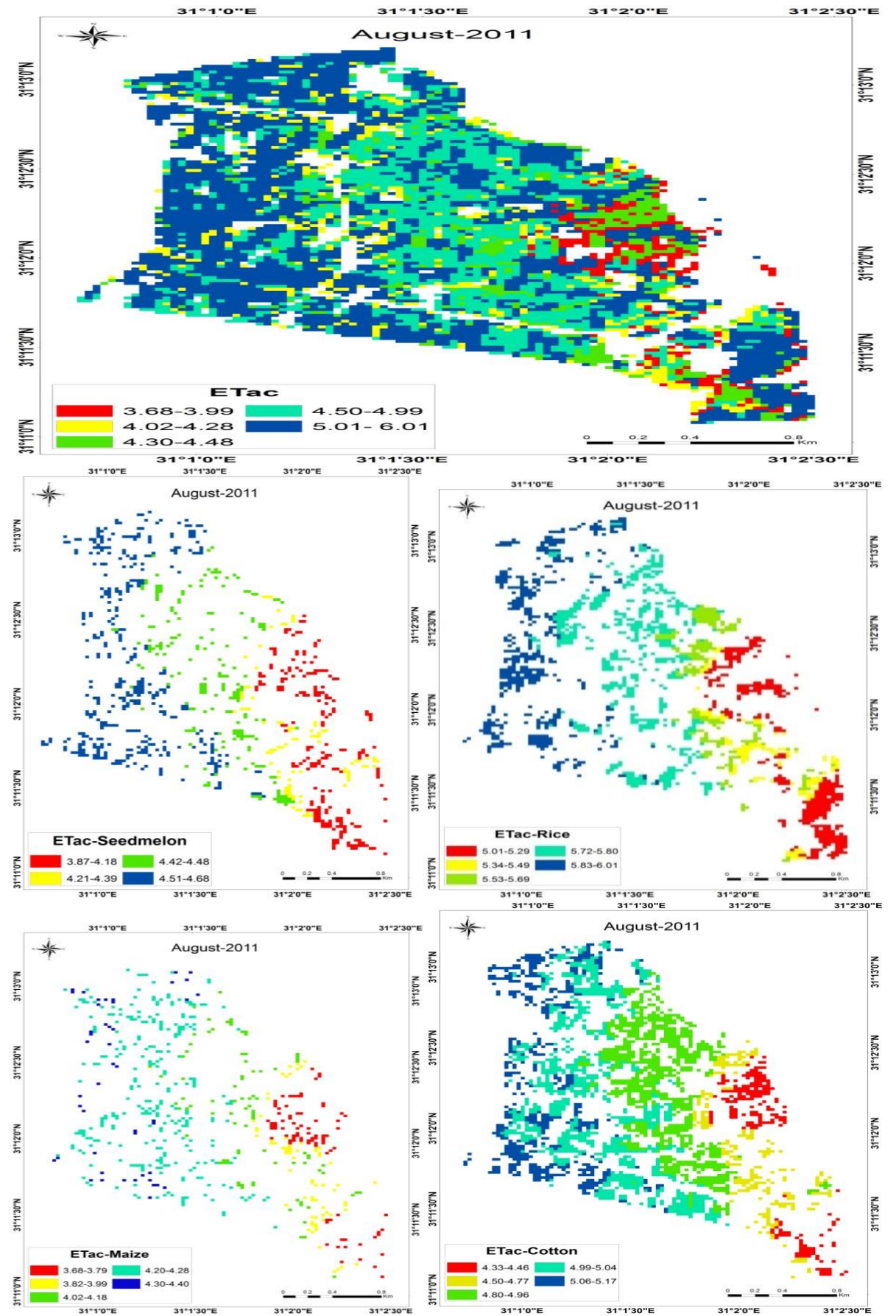

Fig (4): Estimated $\mathrm{ET}_{\mathrm{c}}(\mathrm{mm})$ for summer crops in August (2011) extracted from Landsat data. 


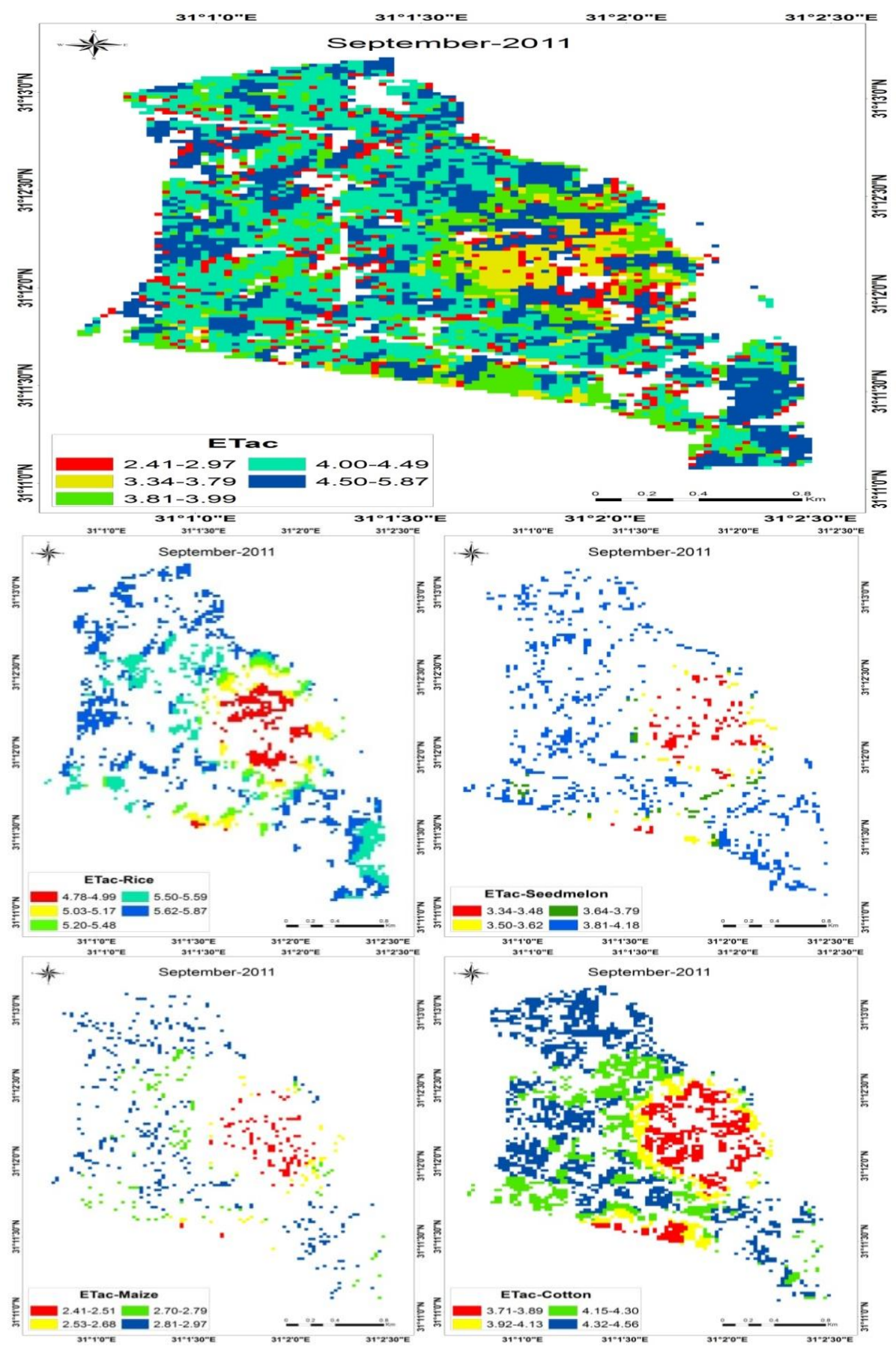

Fig (5): Estimated $\mathrm{ET}_{\mathrm{c}}(\mathrm{mm})$ for summer crops in September (2011) extracted from Landsat data. 
El-Hadidy, E. M. et al.

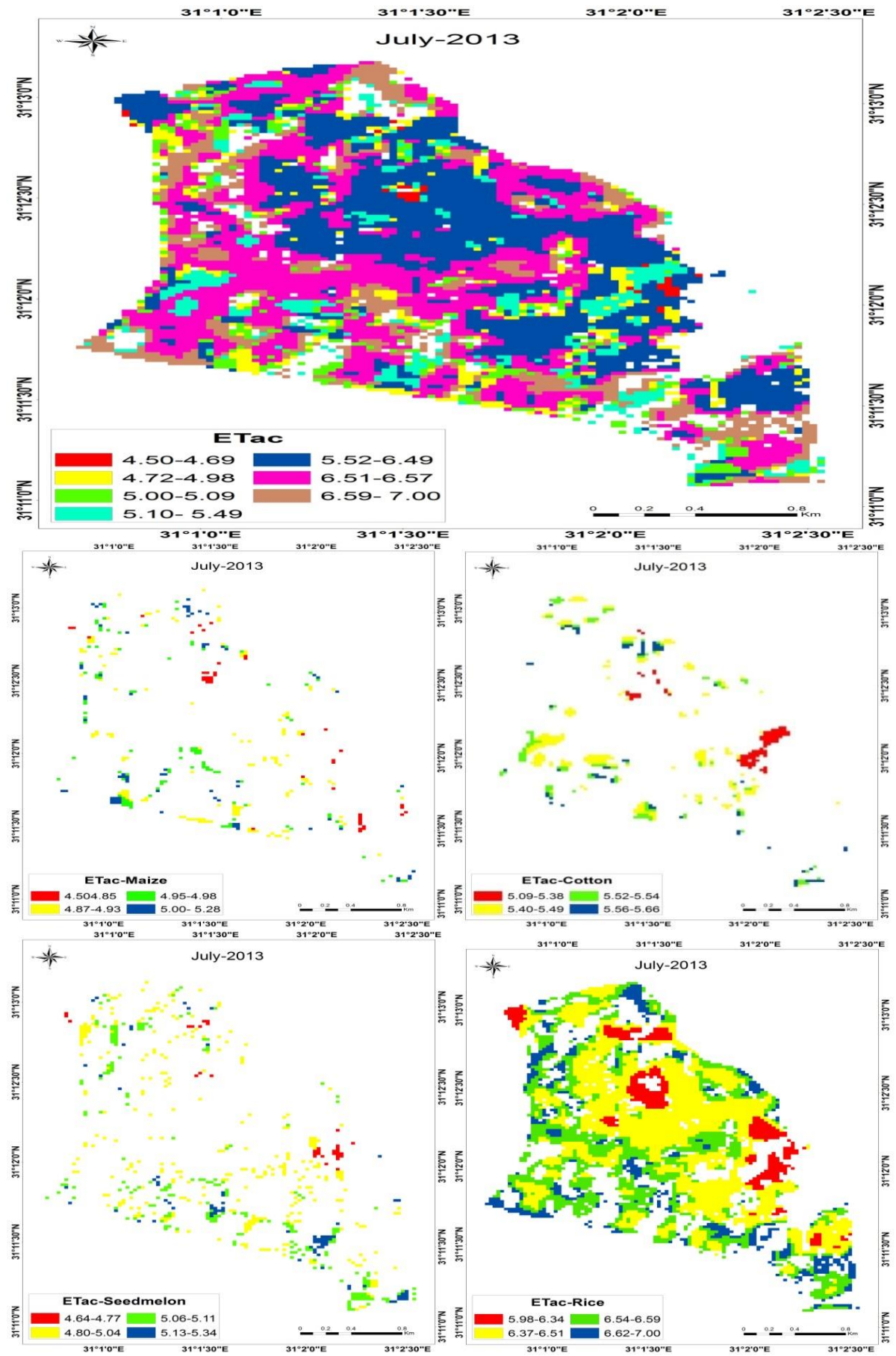

Fig (6): Estimated $\mathrm{ET}_{\mathrm{c}}(\mathrm{mm})$ for summer crops in July (2013) extracted from Landsat data. 
J. Soil Sci. and Agric. Eng., Mansoura Univ., Vol. 5 (4), April, 2014

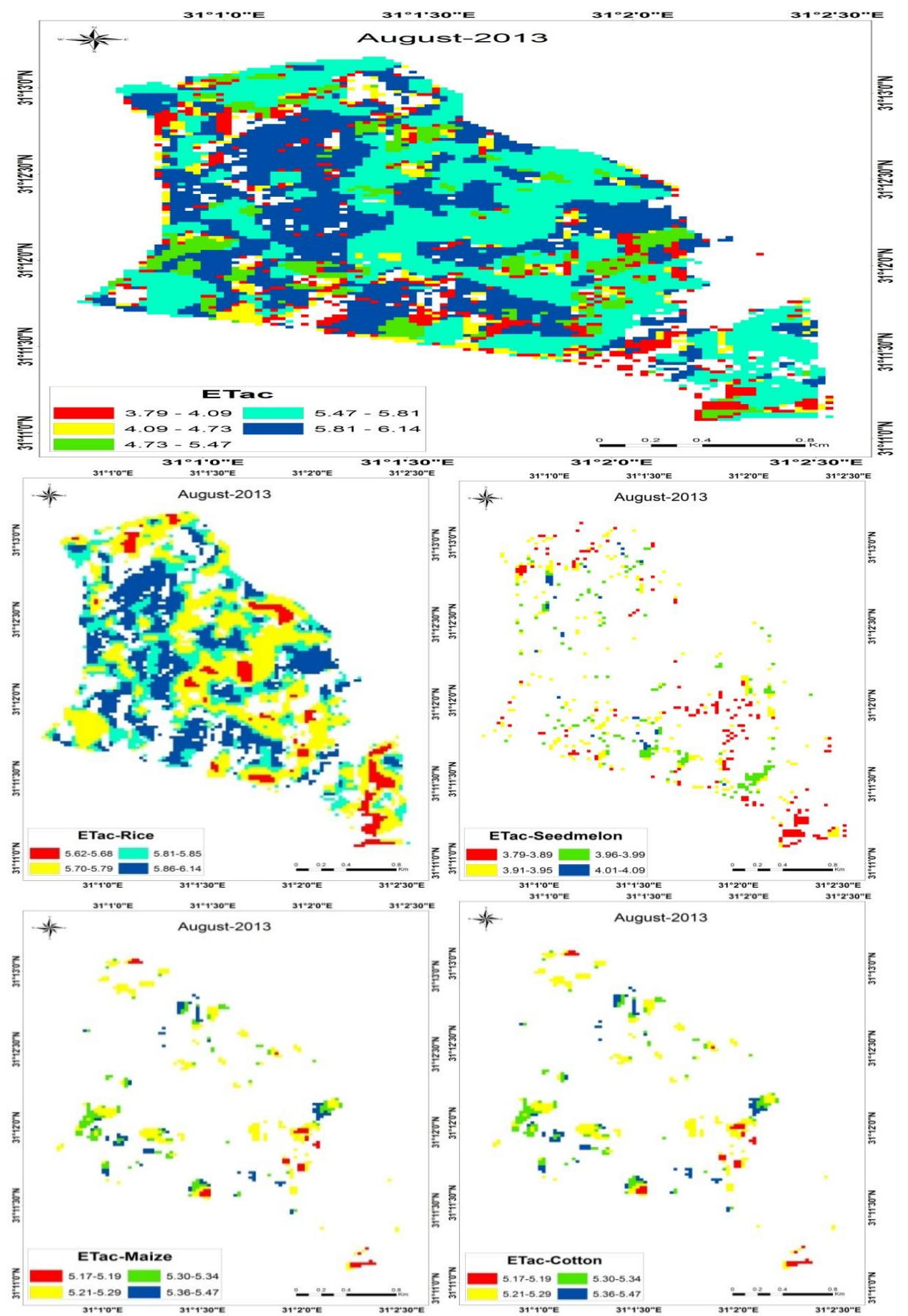

Fig (7): Estimated $\mathrm{ET}_{\mathrm{c}}(\mathrm{mm})$ for summer crops in August (2013) extracted from Landsat data. 
El-Hadidy, E. M. et al.

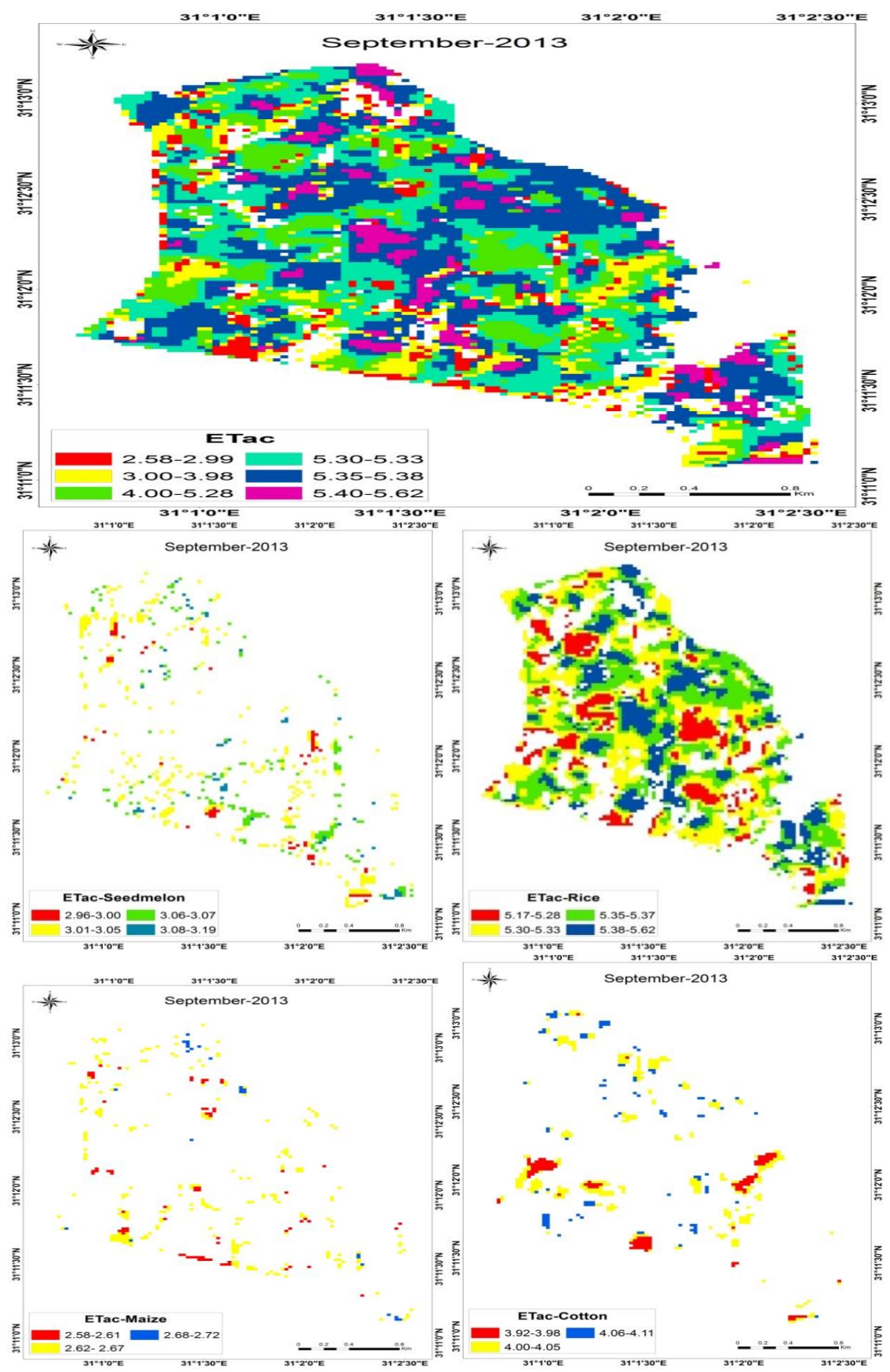

Fig (8): Estimated $\mathrm{ET}_{\mathrm{c}}(\mathrm{mm})$ for summer crops in September (2013) extracted from Landsat data. 
For comparing ETc values within the branch canal, head-tail analysis was carried out with respect to ETc and water requirements. For the branch canal, the mean ETc for the three equal-area distance intervals was calculated before irrigation improvements (2011) and represented in Table (6). The comparison within the branch canal (head /tail analysis) indicated that the ETc values and water requirement for all crops on the head-reach except for cotton were higher than those on the tail-reach. The ETc values for rice, seed melon and maize on the head-reach were higher than those in the tail-reach by about 54,55 and $11 \%$, respectively, whereas it was decreased by about $20 \%$ for cotton. This trend reflects the crop pattern along the branch canal and indicates that water was more available in its head area before the improvement.

The comparison within the branch canal (head/tail analysis) after the improvement (2013) took an opposite trend to that found before the improvement, especially with cotton and maize, as shown in Table (6). Data indicate that the values of ETc and water requirements for all crops on the head-reach except for maize were higher than those for the tail-reach. The ETc values of rice, cotton and seed melon on the head reach were higher than those in the tail reach by about 8,23 and $55 \%$, respectively, whereas it was decreased by about $12 \%$ for maize. This trend may reflect the distribution of crops along the branch canal, which indicates that equity in water consumption, was improved for all branch canal reaches due to irrigation improvement. Finally, looking at the head-tail ratio, it could be concluded that the situation after improvement (2013) was better than that before improvement (2011) for all crops except maize.

Table (6): Head/Tail analysis for water requirements before and after irrigation improvement

\begin{tabular}{|c|c|c|c|c|c|c|c|c|c|c|c|c|}
\hline \multirow{3}{*}{ Crop } & \multicolumn{5}{|c|}{ Summer season (2011) } & \multicolumn{5}{|c|}{ Summer season (2013) } & \multirow{2}{*}{\multicolumn{2}{|c|}{$\begin{array}{l}\text { Head/Tail } \\
\text { Ratio }\end{array}$}} \\
\hline & \multicolumn{3}{|c|}{ Area (ha) } & \multicolumn{2}{|c|}{$\mathrm{ET}_{\mathrm{c}}\left(\mathrm{m}^{2} / \mathrm{area}\right)$} & \multicolumn{3}{|c|}{ Area (ha) } & \multicolumn{2}{|c|}{$E T_{c}\left(m^{2} / a r e a\right)$} & & \\
\hline & Head & Meddle & Tail & Head & Tail & Head & Meddle & Tail & Head & Tail & 201 & 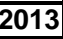 \\
\hline Rice & 76.6 & 55.2 & 49.7 & 420534 & 272853 & 132.5 & 131.7 & 122.4 & 731003 & 675281 & 1.54 & 1.08 \\
\hline Cotton & 63.6 & 89.6 & 79.6 & 295931 & 370379 & 16.3 & 18.6 & 13.3 & 74377 & 60688 & 0.80 & 1.23 \\
\hline S. melon & 30.0 & 29.8 & 19.3 & 128790 & 82855 & 23.2 & 17.7 & 15.0 & 91246 & 58995 & 1.55 & 1.55 \\
\hline Maize & 18.5 & 17.0 & 16.6 & 73760 & 66184 & 8.6 & 12.6 & 9.8 & 31192 & 35545 & 1.11 & 0.88 \\
\hline Total & 188.7 & 191.6 & 165.2 & 919014 & 792271 & 180.6 & 180.6 & 160.5 & 927817 & 830508 & 1.16 & 1.12 \\
\hline
\end{tabular}

Comparison between 2011(before the improvement) and 2013 (after the improvement) is represented in Table (7). It could be concluded from the Landsat data that the overall water consumption (ETc//ha) and water requirements were decreased between 2011 and 2013. The obtained data provide water consumption ( $\mathrm{m} 3 / \mathrm{ha}$ ) in addition to the changes in water consumption for rice, cotton, seed melon and maize separately along ElMoheet canal command area during the three available months. The ETc values revealed that rice was slightly consuming more water in 2013 than in 2011 (+ $0.5 \%)$, whereas its water requirements/ha were decreased after irrigation improvement in 2013 by about $13.9 \%$. Also, the total water requirements for the rice area were increased by about $83.5 \%$ due to 
increase in its ETc and its area. However, water consumption (ETc, m3/ha) for cotton, seed melon and maize, was decreased in 2013 by about 1.9, 8.4 and $9.0 \%$, respectively, whereas the corresponding water requirements were decreased by about $14.2,19.8$ and $20.4 \%$, respectively. Furthermore, data indicated that less water was consumed $(\mathrm{ETC} / \mathrm{ha})$ for El-Moheet by about $4.3 \%$ in 2013 (after completion of Irrigation Improvement and Integrated Management Project, IIIMP) as compared to the baseline year 2011 (before IIIMP). However, water requirements for all area were decreased by about $6.3 \%$ or by about $2.1 \%$ for water requirements/ha. Since the meteorological differences were negligible, the increase in ETc could be attributed to the more availability of water resources, whereas the decrease in water requirements was related to water saving as a result of irrigation improvement. These results are in harmony with those obtained by WaterWatch (2002 and 2003).

Table (7): Comparison between the consumptive uses for improved vs unimproved area for different crops.

\begin{tabular}{|l|c|c|c|c|c|c|c|c|c|c|c|}
\hline \multirow{3}{*}{ Crop } & \multicolumn{4}{|c|}{ Summer 2011 } & \multicolumn{4}{c|}{ Summer 2013 } & \multicolumn{3}{c|}{ Differences \% } \\
\cline { 2 - 13 } & Area & ETc & W.requirement & Area & Etc & W.requirement & \multicolumn{2}{c|}{ ETc } & W.requirement \\
\cline { 2 - 13 } & (ha) & $\mathbf{m 3 / h a}$ & $\mathbf{m 3 / h a}$ & $\mathbf{m 3 / a r e a}$ & (ha) & $\mathbf{m 3 / h a}$ & $\mathbf{m 3 / h a}$ & $\mathbf{m 3 / a r e a}$ & ha & ha & area \\
\hline Rice & 181.5 & 5490 & 9150 & 1660725 & 386.6 & 5517 & 7881 & 3046795 & 0.5 & -13.9 & 83.5 \\
\hline Cotton & 232.8 & 4653 & 6647 & 1547422 & 48.2 & 4563 & 5704 & 274932.8 & -1.9 & -14.2 & -82.2 \\
\hline Seed melon & 79.1 & 4293 & 6133 & 485120 & 55.9 & 3933 & 4916 & 274804.4 & -8.4 & -19.8 & -43.4 \\
\hline Maize & 52 & 3987 & 5696 & 296192 & 31.1 & 3627 & 4534 & 141007.4 & -9 & -20.4 & -52.4 \\
\hline Planted area & 545.4 & - & - & 3989459 & 521.8 & - & - & 3737539 & - & - & -6.3 \\
\hline Mean & - & 4606 & 7315 & - & - & 4410 & 7163 & - & -4.3 & -2.1 & - \\
\hline
\end{tabular}

\section{Conclusion:}

It could be concluded that the regular distribution of crops or crop pattern depends mainly on the situation of irrigation system and consequently on the distribution equity of water along the branch canal. In this work cotton was the dominant crop before irrigation improvement, whereas, rice became the dominant crop after improvement. Improving the irrigation system saves irrigation water and raises the distribution equity of water and consequently the crop distribution regularity improves along the improved irrigation canal. Crop distribution regularity should be achieved to maintain soil fertility.

Remote sensing techniques have the potential to provide the ability to detect and quantify the spatial differences in ETc information and crop growth stages. This technique could minimize the additional filed observations. Remote sensing based Kc estimation follow the similar pattern of seasonal variation of crop fraction. Since the meteorological differences were negligible, the changes in ETc could be attributed to the more availability of water resources. On the other hand, the decrease in water requirements was related to water saving as a result of irrigation improvement. 


\section{REFERENCES}

Ahmad, M.D., Stein, A. and Bastiaanssen, W.G.M. (2004): Estimation of disaggregated canal water deliveries in Pakistan using geometrics. International Journal of Applied Earth Observation and Geoinformation, 6(1):63-75.

Almhab, A and Busu, I. (2008). "Decision Support System or Estimating Actual crop Evapotranspiration using Remote Sensing, GIS and Hydrological Models".In: 7th Annual Asian Conference \& Exhibition on Geopastial Information, Technology and Application, 18-20 August 2008, Kuala Lumpur Convention Centre, Kuala Lumpur, Malaysia.

Anderson, M.C., Allen, R. G., Morse, A. and Kustas, W.P. (2012). Use of Landsat thermal imagery in monitoring Evapotranspiration and managing water resources. Remote Sensing of Environment. Volume 122, July 2012, Pages 50-65, Landsat Legacy Special Issue

Bastiaanssen, W.G.M. (1998). Remote sensing in water resources management; the state of the art, Monograph, International Water Management Institute (IWMI), Colombo, Sri Lanka: pp.118.

Bleiweiss, M., Samani, Z., Bawazir, S. and Skaggs, R. (2010). Estimating Water Use through Satellite Remote Sensing. Mexico Water Resources Research Institute, New Mexico State University http://wrri.nmsu.edu

Bos, M.G., Abdel Dayem, S., Bastiaanssen, W. and Vidal, A. (2001): Remote Sensing for Water Management: The Drainage Component. Report Ede-Wageningen Expert Consultation Meeting, May 15 to 16, China.

Campbell,J.B.(1996):Introduction to Remote Sensing,Taylor Francis, London.

Denis, D. M. (2013): Irrigation Performance Assessment using SEBS and SCOPE. A case study of Tons pump Canal Command in India. Master Thesis of Science in Geo-information Science and Earth Observation, Faculty of Geo-Information Science and Earth Observation, University of Twente, Enschede, The Netherlands.

Elhaddad, A., Garcia, L.A. and Gates, T.K. (2007): A Remote Sensing - GIS Approach to Evaluate the Effects of Soil Salinity on Evapotranspiration . Hydrology Days, Colorado State University, Fort Collins, CO, USA.

El-Shirbeny .M.A. (2012):Modeling yield response to water under climate change conditions. Ph.D Thesis, Faculty of Agric., Ain Shams Univ.

Hargreaves,G.H., and Samani,Z.A. (1985): Reference crop evapotranspiration from temperature, Applied Engineering in Agriculture, 1: 96-99.

Hofwegen, van, P. and Svendsen, M. (2000): A vision of water for food and rural development, World Water Forum, 17 March 2000, The Hague, The Netherlands

Jackson,M.L.(1967):Soil Chemical Analysis. Prentice-Hall of India,New Delhi.

Kurucu, Y., Altınbaş, Ü. and Bolca, M. (2000): Determination of the Cotton Covers and Yields in Aegean Region Using Sensing Techniques. Department of Soil Science, Faculty of Agriculture, Aegean University, Bornova-İzmir, pp. 32. 
Öztekin, M.E. (2012): Monitoring and determination of land use types in large-scale irrigation project areas in Mediterranean region of Turkey. Food, Agric \& Environ, 10 (2): 1065-1068.

Popova, Z., Kercheva, M., and Pereira, L.S. (2005): Validation of the FAO methodology for computing ETo with limited data, ICID $21^{\text {st }}$ European Regional Conference, Frankfurt, Slubice.

Raju , P.V., Sesha Sai, M.V.R. and Roy, P.S. (2008): In-season time series analysis of Resourcesat-1 AWiFS data for estimating irrigation water requirement. International Applied Earth Observation and Geoform, 10(2): 220-228.

WaterWatch (2002): Remote sensing monitoring in the Awati pilot area, the possibilities of operational remote sensing to support land and water management planning, World Bank report, pp. 36. info@waterwatch.nl.

WaterWatch (2003): Monitoring of summer crops under changing irrigation practices, A Remote Sensing Study in the North-western Nile Delta for the Irrigation Improvement Project, 1995 - 2002, version 1. info@waterwatch.nl.

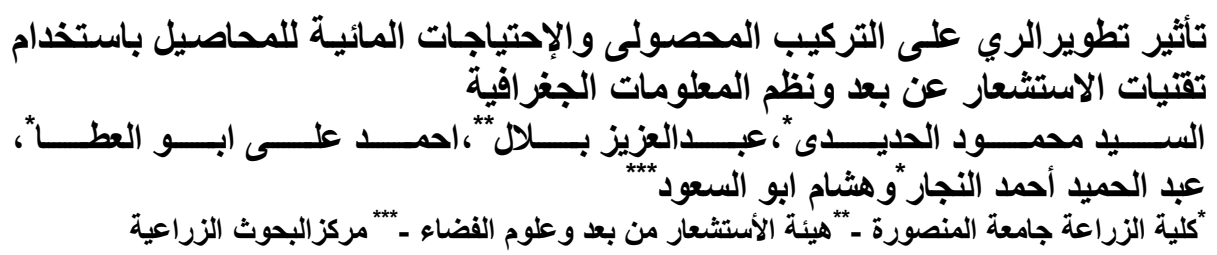

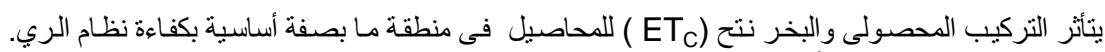

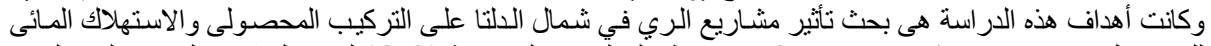

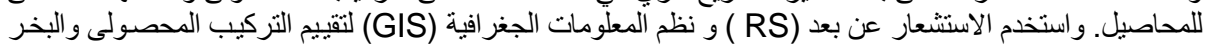

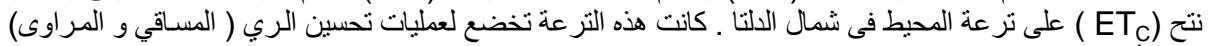
و وقد أجريت هذه الدراسة من خلال اثين من مواسم الزراعة الصيفية ( 2011، قبل التحسين و 2013 ، بعد التحسين

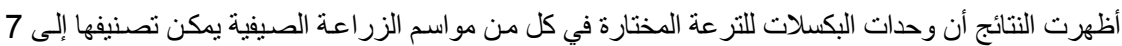

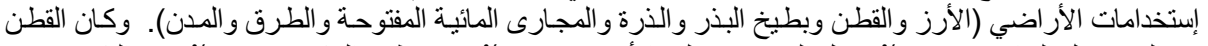

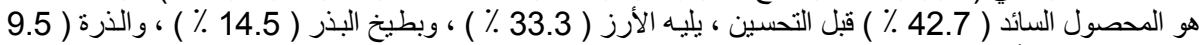

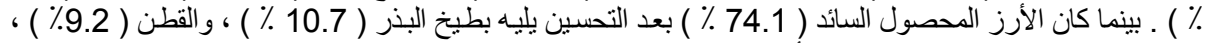

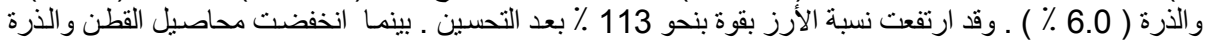

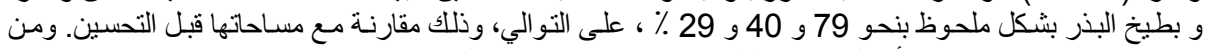

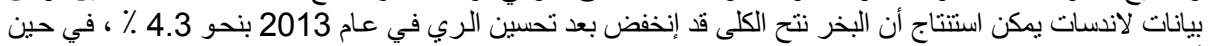

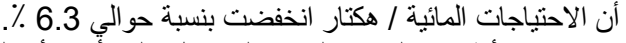

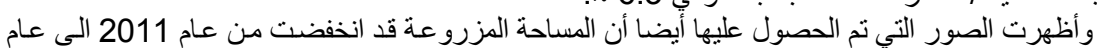

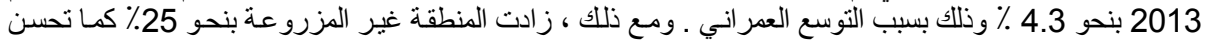

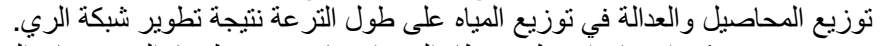
ويمكن إستنتاج آن تطوير نظام الري قد ساهم فى حفظ مياه الري ولئ وزيادة العدالة فى توزيع المياه على طول

كلية الزراعة - جامعة المنصورة

$$
\text { مركز البحوث الزراعية }
$$

$$
\begin{aligned}
& \text { الترعة. } \\
& \text { قام بتحكيم البحث } \\
& \text { أ.د / زكريا مسعد الصيرفى اليف } \\
& \text { أ.د / محمد ابراهيم مليحة }
\end{aligned}
$$


J. Soil Sci. and Agric. Eng., Mansoura Univ., Vol. 5 (4), April, 2014 